\title{
MANAJEMEN PENGEMBANGAN PROFESIONALISME GURU DI SMP NEGERI 3 JETIS BANTUL
}

\author{
Halomoan Mangasi Siadari, Wuradji \\ ITN Malang, Universitas Negeri Yogyakarta \\ halomoan7dri@yahoo.com
}

\begin{abstract}
Abstrak
Penelitian ini bertujuan untuk mengetahui manajemen pengembangan profesionalisme guru di SMP Negeri 3 Jetis Bantul. Penelitian ini menggunakan metode kualitatif, dan sumber data dipilih secara purposive. Subjek penelitian adalah kepala sekolah, wakil kepala sekolah, guru dan siswa SMP Negeri 3 Jetis Bantul. Teknik pengumpulan data yang digunakan ada-lah wawancara, observasi, dan dokumentasi. Teknik pemeriksaan keabsahan data menggu-nakan teknik triangulasi. Data dianalisis dengan mereduksi data, menyajikan data dan pengambilan kesimpulan. Hasil penelitian sebagai berikut: kondisi profesionalisme guru di SMP Negeri 3 Jetis Bantul menurut data kualifikasi akademik yang qualified adalah 94,87\%, sedangkan 5,13\% adalah underqualified. Program pengembangan profesionalisme sebagai berikut. (1) Masih terdapat guru mismatched, kurang memanfaatkan kesempatan pendidikan dan pelatihan yang ada, anggaran dan motivasi diri. (2) Pelaksanaan program pengembangan profesionalisme SDM dalam rangka meningkatkan profesionalisme guru berupa: pelatihan sosialisasi KTSP dan pelatihan komputer, studi lanjut, MGMP, seminar, workshop, penambahan koleksi buku-buku di perpustakaan, kerja sama dengan Dinas Pendidikan DIY, Dinas Pendidikan Kabupaten Bantul, Kanwil DIY dan intansi terkait. (3) Penghambat pelaksanaan program pengembangan SDM: terbatasnya anggaran, kurangnya minat dan motivasi guru. (4) Untuk mengatasi hambatan: mengajukan penambahan anggaran, memberi motivasi, reward, dan kerja sama dengan intansi terkait.
\end{abstract}

Kata kunci: manajemen, pengembangan, profesionalisme guru

\section{THE MANAGEMENT OF TEACHERS' PROFESSIONAL DEVELOPMENT IN SMP NEGERI 3 JETIS BANTUL}

\begin{abstract}
This study aims to investigate the management of the professional development of the teachers of SMP Negeri 3 Jetis Bantul. This was a qualitative study in which the data source was purposively selected. The research subjects comprised the principal, vice principals, teachers, and students of SMP Negeri 3 Jetis Bantul. The data were collected through interviews, observations, and documentation, followed by enhancing the data trustworthiness. They were analyzed through data reduction, data display, and conclusion drawing. The results of this study are as follows. In terms of the teachers' professionalism in SMP Negeri 3 Jetis Bantul based on the data of the academic qualifications eligible for teachers of the secondary educational level, $94.87 \%$ of them are qualified and $5.13 \%$ are unqualified. In terms of the professional development program, is as follows. (1) There are still mismatched teachers who do not take the advantages of their education and training, (2) The implementation of the human resources' professional development program to develop teachers' professionalism is in the form of: the training on the school-based curriculum socialization, computer training, further study, the Forum of Subject Matter Teachers, seminars, and workshops, adding books to the collection in the library, making a cooperation with the Office of Education of the of Yogyakarta Special Territory (YST), the Office of Education of Bantul Regency, and other related institutions (3) The constraints in the implementation of the human resources' development program, among others: the limited school budget, low interest, and motivation of the teachers. (4) The way to overcome such constraints is as follows'. To propose an additional budget to RAPBS, give motivation and rewards, and make cooperation with related institutions.
\end{abstract}

Keywords: management, development, teacher professionalism 


\section{Pendahuluan}

Guru sebagai pendidik adalah tokoh yang paling berperan dalam meningkatkan kualitas pendidikan yang bertumpu pada kualitas proses belajar mengajar. Guru secara langsung berupaya mempengaruhi, membina dan mengembangkan peserta didik, juga guru dituntut untuk memiliki kemampuan dasar yang diperlukan sebagai pendidik, pembimbing dan pengajar dan kemampuan tersebut tercermin pada kompetensi guru. UU Nomor 20 tahun 2003 tentang Sistem Pendidikan Nasional, menyatakan bahwa "guru atau pendidik mencakup semua elemen yang ikut serta dalam mencerdaskan anak bangsa", sebagaimana dinyatakan dalam Bab I Pasal 1 ayat 6: "Pendidik adalah tenaga kependidikan yang berkualifikasi sebagai guru, dosen, konselor, pamong belajar, widyaiswara, tutor, instruktur, fasilitator dan sebutan lain sesuai dengan kekhususannya, serta berpartisifasi dalam menyelenggarakan pendidikan".

Selanjutnya dalam Bab XI Pasal 39 ayat 2, dinyatakan bahwa "pendidik (guru) merupakan tenaga profesional yang bertugas merencanakan dan melaksanakan proses pembelajaran, menilai hasil pembelajaran, melakukan pembimbingan dan pelatihan, serta melakukan penelitian dan pengabdian kepada masyarakat, terutama bagi pendidik pada perguruan tinggi".

Hal ini dipertegas lagi dalam UU RI nomor 14 tahun 2005 tentang Guru dan Dosen, Bab I Pasal 1 ayat 1, bahwa yang dimaksud dengan guru adalah pendidik profesional dengan tugas utama mendidik, mengajar, membimbing, mengarahkan, melatih, menilai, dan mengevaluasi peserta didik pada pendidikan anak usia dini jalur pendidikan formal, pendidikan dasar, dan pendidikan menengah". Pada ayat 4 dinyatakan bahwa "profesi pekerja profesional adalah pekerjaan atau kegiatan yang dilakukan oleh seseorang dan menjadi sumber penghasilan kehidupan yang memerlukan keahlian, kemahiran, atau kecakapan yang memenuhi standar mutu atau norma tertentu serta memerlukan pendidikan profesi". Oleh karena itu profesionalisme guru merupakan suatu keharusan bagi seorang pendidik. Guru profesional tidak hanya menguasai bidang ilmu, bahan ajar, dan metode tapi juga harus mampu memotivasi peserta didik, memiliki keterampilan yang tinggi dan wawasan yang luas akan dunia pendidikan. Guru yang profesional juga harus memiliki pemahaman yang mendalam tentang makna hidup dan kehidupan dalam masyarakat. Pemahaman ini akan melandasi pola pikir dan pola kerja guru serta loyalitasnya terhadap profesi pendidikan. Dalam implementasi kegiatan belajar mengajar, guru harus mampu mengembangkan budaya organisasi kelas, dan iklim organisasi pengajaran yang bermakna, kreatif dan dinamis, bergairah, dialogis sehingga menyenangkan bagi peserta didik.

Guru profesional sesuai yang disyaratkan oleh UU RI Nomor 20 Tahun 2003 tentang Sistem Pendidikan Nasional Pasal 40 ayat 2 "(a) bahwa pendidik dan tenaga kependidikan berkewajiban: menciptakan suasana pendidikan yang bermakna, menyenangkan, kreatif, dinamis dan dialogis dan (b) mempunyai komitmen secara profesional untuk meningkatkan mutu pendidikan". Dalam hal ini pendidik diharapkan: pertama, memiliki dasar ilmu yang kuat sebagai pengetahuan terhadap masyarakat teknologi dan masyarakat ilmu pengetahuan di abad 21 . Kedua, memiliki kiat-kiat profesi berdasarkan riset dan praktik pendidikan yaitu ilmu pendidikan sebagai ilmu praktis bukan hanya merupakan konsep-konsep belaka.

Guru diyakini sebagai salah satu faktor dominan yang menentukan tingkat keberhasilan peserta didik dalam melakukan proses belajar mengajar di sekolah. Ujung tombak pelaksanaan pendidikan adalah guru di kelas. Selama ini, ahli-ahli pendidikan telah menyadari bahwa kualitas pendidikan sangat bergantung pada kualitas guru dan praktek-praktek pengajarannya. Ada beberapa kemungkinan penyebab kurang optimalnya guru dalam 
mengajar, antara lain, yaitu: pertama guru gagal memperbaiki strategi pembelajarannya. Kedua guru tidak berusaha untuk memperbaiki cara pembelajarannya, ketiga guru ingin berusaha untuk memperbaiki pembelajarannya, tetapi tidak mengetahui carannya.

Kondisi riil menunjukkan bahwa guru dalam menjalankan tugasnya menemui banyak masalah. Masalah-masalah ini berkaitan dengan guru dan keguruan, biasanya tentang kurang memadainya kualitas guru, kurangnya tingkat kesejahteraan guru, rendahnya etos kerja dan komitmen guru serta kurangnya penghargaan masyarakat tentang profesi guru. Kesempatan pemberdayaan sumber daya manusia kurang dipergunakan oleh para guru, baik melalui penataran, keikutsertaan untuk mengikuti seminar pendidikan, pendidikan lanjut gelar, maupun keterlibatan secara aktif untuk mengikuti berbagai kegiatan ilmiah terutama pendalaman materi mata pelajaran yang diajarkannya. Akibatnya informasi pengetahuan yang diberikan guru kepada siswa hanya terbatas pada pengetahuan dan pengalaman yang dimi-liki oleh guru yang bersangkutan.

Hambatan lain yang juga mempengaruhi profesionalisme guru, masih terbatasnya jumlah guru yang mengajar, sehingga banyak guru yang merangkap dalam mengajar. Selain itu masih ada beberapa guru yang mengajar tetapi tidak sesuai dengan pendidikan yang dimiliki oleh guru sehingga dalam penyampaian materi terhadap peserta didik mengalami beberapa masalah, seperti peserta didik mengalami kesulitan untuk mengerti dan memahami materi yang disampaikan. Selain itu terbatasnya sarana dan prasarana pendidikan, seperti komputer, ruang laboratorium, ruang perpustakaan, serta koleksi buku-buku di perpustakaan telah menyebabkan semangat guru dan peserta didik mengalami penurunan. Bila hal ini dibiarkan tentunya akan mempengaruhi efektivitas pelaksanaan proses belajar mengajar.
Hamzah B. Uno (2007, p.17) menyatakan "apabila seseorang ingin menjadi guru yang profesional maka sudah seharusnya dapat selalu meningkatkan wawasan pengetahuan akademis dan praktis melalui jalur pendidikan berjenjang ataupun upgrading dan/atau pelatihan yang bersifat in service training dengan rekan-rekan sejawatnya".

Profesionalisme seorang guru merupakan suatu keharusan dan tuntutan yang harus dipenuhi untuk mewujudkan sekolah. Seorang guru dapat dikatakan professional apabila memiliki kompetensi tertentu. Adapun macam-macam kompetensi yang harus dimiliki oleh seorang guru menurut Undang-Undang Nomor 14 Tahun 2005 Tentang Guru dan Dosen pasal 10 ayat (1) adalah: 1) Kompentesi pedagogik, yaitu kemampuan dalam mengelola pembelajaran peserta didik, 2) Kompetensi kepribadian, yaitu kemampuan kepribadian yang mantap, berakhlak mulia, arif dan berwibawa serta menjadi teladan peserta didik, 3) Kompetensi sosial, yaitu kemampuan penguasaan materi secara luas dan mendalam, 4) Kompetensi profesional, yaitu kemampuan guru untuk berkomunikasi dan berinteraksi secara efektif dan efisien dengan peserta didik, sesama guru, orang tua/wali peserta didik dan masyarakat sekitar. Hasil prasurvey di SMP Negeri 3 Jetis Bantul, peneliti mendapat informasi langsung dari kepala sekolah sebagai pimpinan di lembaga tersebut dan kepala sekolah merupakan sumber informan yang mengetahui keadaan sumber daya guru yang ada. Sesuai dengan hasil wawancara dengan kepala sekolah mengenai keprofesionalan guru sebagai pendidik yang bertanggung jawab langsung terhadap kemajuan proses belajar peserta didik. Kepala sekolah menyatakan bahwa keadaan guru di SMP Negeri 3 Jetis Bantul masih ditemui kurangnya keprofesionalan guru dalam melaksanakan tugasnya sebagai pendidik. Dalam usaha meningkatkan keprofesionalan guru di sekolah tersebut masih ada juga guru yang berprestasi dalam lingkup regional bahkan prestasi nasional seperti: menjadi guru 
instruktur dan tim pengembang KTSP Nasional Direktorat PSMP mulai dari Tahun 2006 sampai sekarang, Juara 1 lomba kreasi dan inovasi media pembelajaran nasional pada Tahun 2010 dan 2011, juga guru prestasi nasional Tahun 2010, bahkan juara 1 guru award Jateng-DIY pada Tahun 2011. Prestasi guru yang ada di SMP Negeri 3 Jetis Bantul sangat memotivasi semangat siswa untuk berprestasi secara nasional dan internasional. Bahkan secara hasil kelulusan secara nasional siswa SMP Negeri 3 Jetis Bantul pada Tahun 2012 UN lulus $100 \%$. Prestasi guru juga merupakan modal besar bagi tercapainya visi dan tujuan pendidikan yang telah dirumuskan.

Mendasarkan pada informasi tersebut menarik untuk mengkaji tentang manajemen pengembangan profesionalisme guru di Kabupaten Bantul, dan memilih Sekolah SMP Negeri 3 Jetis Bantul.

Dari uraian di atas, dapat digambarkan bahwa guru yang profesional merupakan kebutuhan yang nyata dalam upaya meningkatkan mutu pendidikan sehingga peningkatan profesionalisme guru perlu dilakukan terus menerus dan berkesinambungan. Upaya peningkatan profesionalisme tersebut tentu saja perlu melibatkan berbagai pihak yang berkompeten dalam penentu kebijakan dan guru itu sendiri. Oleh karena itu upaya peningkatan profesionalisme guru di segala bidang yang berkaitan dengan pendidikan merupakan pendorong terciptanya profesionalisme guru ke arah yang lebih baik, karena guru bekerja dalam suatu sistem yang dikendalikan oleh manajemen. Upaya yang harus dilakukan dalam rangka memperbaiki mutu sumber daya manusia adalah dengan meningkatkan mutu pendidikan. Fokus utama yang harus diperhatikan dalam peningkatan mutu pendidikan adalah peningkatan institusi sekolah sebagai basis utama pendidikan, baik aspek manajemen, sumber daya manusianya, maupun sarana dan prasarananya.

Berdasarkan dari permasalahan yang dipaparkan di atas, peneliti terdorong untuk melakukan kajian lebih jauh terha- dap keberadaan para guru di SMP Negeri 3 Jetis Bantul.

Pengembangan Sumber Daya Manusia

Konsep Pengembangan Sumber Daya Manusia

Pengembangan SDM merupakan salah satu bentuk aktivitas dari manajemen sumber daya manusia, seperti dijelaskan oleh Husaini Usman, (2011, p.226) bahwa: Pengembangan SDM merupakan bagian dari manajemen SDM. Pengembangan SDM adalah proses meningkatkan kuantitas dan kualitas SDM. Peningkatan kualitas SDM dapat dilakukan melalui pengamalan agama, peningkatan kesejahteraan, peningkatan pendidikan, peningkatan pelatihan, peningkatan kesehatan, peningkatan kesempatan kerja, pengendalian kependudukan, peningkatan lingkungan hidup, dan perencanaan karier.

Pengembangan menurut Beebe, Mottet, \& Roach (2004, p.8) adalah:

The concept of development is a process often linked to both training and human resource. The word development added to other terms suggests a broadening of the behaviors or strategis to achieve a goal. Development is any behavior, strategy, design, restructuring, skill or skill set, strategic plan, or motivational effort that is designed to produce growth or change over time. Devolepment is a process of helping the organization or individuals in the organization do their jobs more effectively. Development involves a set of strategies that can help an individual or organization change to perform more effectively in achieving individual or corporate vision, mission, and goals.

Pengembangan SDM terbagi menjadi dua bentuk, yaitu pelatihan dan pengembangan (training and development). Program pelatihan dan pengembangan merupakan serangkaian aktifitas yang dirancang untuk meningkatkan pengetahuan, kemampuan, sikap dan kinerja individu, kelompok atau seluruh organisasi. Aktivitas ini mengajarkan keahlian baru, memperbaiki keahlian yang ada, dan mempengaruhi sikap karyawan. Aktivitas keah- 
lian dirancang untuk meningkatkan keahlian pada pekerjaan saat ini. Sebagai contoh karyawan dapat dilatih dalam teknik pengambilan keputusan atau kemampuan dalam sistem pengolahan data. Aktivitas pengembangan dirancang supaya mendidik karyawan di luar keperluan posisi, sehingga dipersiapkan untuk promosi dan mampu memandang peran dalam organisasi secara lebih luas.

Sementara itu, Soekidjo Notoatmodjo (1992, p.4) mengemukakan bahwa: untuk meningkatkan kualitas fisik dapat diupayakan melalui program-program kesehatan dan gizi. Sedangkan untuk meningkatkan kualitas atau kemampuankemampuan nonfisik tersebut maka upaya pendidikan dan pelatihan adalah yang paling diperlukan.

Lebih lanjut mengungkapkan bahwa yang dimaksud dengan sumber daya manusia secara makro adalah suatu proses perencanaan pendidikan, pelatihan, dan pengelolaan tenaga atau karyawan untuk mencapai suatu hasil yang optimal. Hasil ini dapat berupa jasa maupun benda.

Tujuan Pengembangan Sumber Daya Manusia

Pengembangan SDM bertujuan dan bermanfaat bagi organisasi, karyawan atau masyarakat yang menggunakan barang/ jasa yang dihasilkan. Oleh karena itu, dalam pengembangan, harus dituangkan sasaran, kebijaksanaan, prosedur, anggaran, peserta, kurikulum dan waktu pelaksanaannya. Program pengembangan harus berprinsipkan pada peningkatan efektifitas dan efisiensi kerja masing-masing pegawai pada jabatannya.

Keuntungan adanya pengembangan sumber daya manusia dalam sebuah organisasi menurut Decenzo \& Robbins (1999, p.232) adalah sebagai berikut: Pengembangan memberikan pendidikan yang diperlukan oleh pegawai dalam memahami dan menginterpretasikan ilmu pengetahuan. (2) Pengembangan memfokuskan pada perkembangan pegawai secara individual. (3) Pengembangan memberikan ilmu pengetahaun yang dibutuhkan secara menyeluruh. (4) Pengembangan menciptakaan sumber daya manusia yang mampu untuk menjabat pekerjaan yang memiliki tanggung jawab yang lebih besar, analitis, memiliki rasa kemanusiaan, terkonsep dan memiliki keterampilan yang khusus. (5) Pengembangan menciptakan sum-ber daya manusia yang mampu untuk berpikir dan memahami secara logis.

Metode Pengembangan Sumber Daya Manusia

Pengembangan SDM ini menurut Decenzo \& Robbins (1999, pp.234-236) terdapat beberapa metode yang merupakan ga-bungan dari metode-metode dalam "onthe job techniques (job rotation, assistant to positions, and committee assignments and off the job methods (lecture courses and seminars, simulation exercises and outdoor training)". 1) Job rotation/rotasi jabatan adalah perpindahan karyawan ke berbagai posisi dalam suatu organisasi yang bertujuan untuk meningkatkan keterampilan, pengetahuan dan kemampuan karyawan. 2) Assistant to position adalah karyawan yang memiliki potensi kadang-kadang diberi kesem-patan untuk bekerja dengan manajer yang berpengalaman dan sukses di divisi lain di organisasi. 3) Committee Assignment adalah sumber daya manusia yang ada dalam institusi pendidikan mendapat kesempatan untuk saling bertukar pendapat dalam hal membuat keputus-an dan belajar dari apa yang dilihat serta menginvestigasi problem -problem khusus dalam organisasi. 4) Simulation exercise adalah suatu peniruan karakteristik atau perilaku tertentu dari dunia yang nyata, sehingga peserta pelatihan dan pendidikan dapat merealisasikan seperti keadaan yang sebenarnya.

Konsep Pendidikan dan Pelatihan Pengembangan SDM

Menurut Beebe, Mottet, \& Roach. (2004, p.6) "education is the process of or importing knowledge or information. People can educate selves them by reading, or they can have one some teach them what they want or need to learn". Pendidikan juga harus mampu menjadikan seseorang memiliki keahlian, memiliki kompetensi untuk berbuat sesuatu dan dari keahlian dan kom- 
petensinya tersebut dapat digunakan untuk mendukung di dalam kehidupannya. Pelatihan (training) merupakan proses pembelajaran yang melibatkan perolehan keahlian, konsep, peraturan atau sikap untuk meningkatkan kerja para karyawan. Pasal 1 ayat 9 UU No. 13 Tahun 2003 tentang ketenagakerjaan mendefinisikan pelatihan kerja adalah keseluruhan kegiatan untuk memberi, memperoleh, meningkatkan, serta mengembangkan kompetensi kerja, produktivitas, disiplin, sikap dan etos kerja pada tingkat keterampilan dan keahlian tertentu sesuai dengan jenjang dan kualifikasi jabatan dan pekerjaan. Pelatihan terdiri atas serangkaian aktivitas yang dirancang untuk meningkatkan keahlian, pengetahuan, pengalaman, ataupun perubahan sikap seseorang.

Lebih lanjut Beebe, Mottet, \& Roach. (2004, p.5) mengemukakan: "training is the process of developing skills in order to more effectively perform a specific job or task". Pelatihan merupakan proses untuk mengembangkan keterampilan secara efektif untuk melaksanakan suatu pekerjaan atau tugas yang spesifik. Kaitan dalam hal ini Soekidjo Notoatmodjo (1992, p. 95) mengemukakan bahwa: Pelatihan-pelatihan ini mencakup antara lain: (1) pelatihan untuk melaksanakan program-program yang baru, (2) pelatihan untuk menggunakan alatalat/fasilitas yang baru, (3) pelatihan untuk pegawai yang akan menduduki job atau tugas-tugas yang baru, (4) pelatihan untuk pengenalan proses atau prosedur kerja yang baru, dan (5) pelatihan bagi pegawai-pegawai yang baru.

Penggunaan istilah pendidikan dan pelatihan dalam semua instansi atau organisasi biasanya disatukan menjadi diklat. Pada dasarnya kedua istilah ini memiliki perbedaan yang cukup berarti. Letak perbedaan tersebut secara teori dapat disajikan pada Tabel 1.
Tabel 1. Perbedaan Antara Pendidikan dan Pelatihan

\begin{tabular}{|c|c|c|c|}
\hline No & Sasaran & $\begin{array}{l}\text { Pendidik- } \\
\text { an }\end{array}$ & Pelatihan \\
\hline 1 & $\begin{array}{l}\text { Pengembang- } \\
\text { an kemampu- } \\
\text { an }\end{array}$ & $\begin{array}{l}\text { Menyelu- } \\
\text { ruh (overall) }\end{array}$ & $\begin{array}{l}\text { Mengkhu- } \\
\text { suskan } \\
\text { (specific) }\end{array}$ \\
\hline 2 & $\begin{array}{l}\text { Area } \\
\text { penekanan }\end{array}$ & $\begin{array}{l}\text { Kognitif, } \\
\text { afektis, } \\
\text { psikomotor }\end{array}$ & Psikomotor \\
\hline 3 & $\begin{array}{l}\text { Jangka waktu } \\
\text { pelaksanaan }\end{array}$ & $\begin{array}{l}\text { Panjang } \\
\text { (long term) }\end{array}$ & $\begin{array}{l}\text { Pendek } \\
\text { (short term) }\end{array}$ \\
\hline 4 & $\begin{array}{l}\text { Materi yang } \\
\text { diberikan }\end{array}$ & $\begin{array}{l}\text { Lebih } \\
\text { umum }\end{array}$ & $\begin{array}{l}\text { Lebih } \\
\text { khusus }\end{array}$ \\
\hline 5 & $\begin{array}{l}\text { Penekanan } \\
\text { penggunaan } \\
\text { metode belajar } \\
\text { mengajar }\end{array}$ & $\begin{array}{l}\text { Konvensio } \\
\text { nal }\end{array}$ & $\begin{array}{l}\text { Inkonven- } \\
\text { sional }\end{array}$ \\
\hline 6 & $\begin{array}{l}\text { Penghargaan } \\
\text { akhir proses }\end{array}$ & $\begin{array}{l}\text { Gelar } \\
\text { (degree) }\end{array}$ & $\begin{array}{l}\text { Sertifikat } \\
\text { (nondegree) }\end{array}$ \\
\hline
\end{tabular}

Sumber : Soekidjo Notoatmodjo, 1992, p.26

Pengertian pendidikan pegawai di sini adalah kegiatan pengembangan SDM untuk meningkatkan total dari pegawai di luar kemampuan di bidang pekerjaan atau jabatan yang dipegang saat ini. Oleh sebab itu pendidikan pegawai dirancang dan diadakan bagi para pegawai yang menempati jabatan atau posisi baru, sehingga tugas-tugas yang akan dilaksanakan perlu memiliki kemampuan-kemampuan khusus dan kemampuan-kemampuan keterampilan yang lain.

Pengertian pendidikan pegawai di sini adalah kegiatan pengembangan SDM untuk meningkatkan total dari pegawai di luar kemampuan di bidang pekerjaan atau jabatan yang dipegang saat ini. Oleh sebab itu pendidikan pegawai dirancang dan diadakan bagi para pegawai yang menempati jabatan atau posisi baru, sehingga tugas-tugas yang akan dilaksanakan perlu memiliki kemampuan-kemampuan khusus dan kemampuan-kemampuan keterampilan yang lain.

Faktor-faktor yang Mempengaruhi Pengembangan SDM

Faktor-faktor dalam pelaksanaan pengembangan SDM menurut Soekidjo Notoatmodjo (1992, pp.10-12): 1) Faktor 
Internal, Faktor internal di sini mencakup keseluruhan kehidupan organisasi yang dapat dilakukan, baik pimpinan maupun anggota organisasi yang bersangkutan. a) Misi dan tujuan organisasi; Setiap organisasi mempunyai misi dan tujuan yang ingin dicapainya. Untuk mencapai tujuan ini, diperlukan perencanaan yang baik dan implementasinya secara tepat. Untuk itu diperlukan kemampuan tenaga sumber daya manusia melalui pengembangan SDM.

b) Strategi pencapaian tujuan: Misi dan tujuan organisasi mungkin sama dengan organisasi lain, tetapi strategi untuk mencapai misi dan tujuan tersebut dapat berbeda. Oleh karena itu, kemampuan karyawan diperlukan dalam memperkirakan dan mengantisipasi keadaan di luar, sehingga strategi yang disusun sudah memperhitungkan dampak yang akan terjadi di dalam organisasinya. c) Sifat dan jenis tujuan : Sifat dan jenis kegiatan organisasi sangat penting terhadap pengembangan SDM. Misalnya, suatu organisasi yang sebagian besar melaksanakan kegiatan teknis, akan berbeda dengan pola pengembangan SDM pada organisasi yang bersifat ilmiah. Demikian juga akan berbeda dengan strategi dan program pengembangan SDM antara organisasi yang kegiatan rutin dan organisasi yang kegiatannya memerlukan inovasi dan kreatifitas. 2) Faktor eksternal, Organisasi itu berada dalam lingkungan dan tidak lepas dari pengaruh lingkungan dimana organisasi itu berada, agar organisasi itu dapat melaksanakan misi dan tujuannya maka harus memperhitungkan faktor-faktor lingkungan atau faktor-faktor eksternal organisasi. a) Kebijakan pemerintah: Kebijakan-kebijakan pemerintah yang baik dikeluarkan melalui perundang-undangan, peraturan-peraturan pemerintah, surat keputusan menteri maupun pejabat pemerintah merupakan arahan yang harus dipertimbangkan oleh organisasi. Kebijakan-kebijakan tersebut akan mempengaruhi program-program pengembangan SDM dalam organisasi yang bersangkutan. b) Sosio budaya masyarakat: Faktor sosio budaya masyarakat tidak dapat diabaikan oleh suatu organisasi. Hal ini dapat dipahami karena suatu organisasi apapun didirikan untuk kepentingan masyarakat yang mempunyai latar belakang sosio budaya yang berbeda-beda. Oleh sebab itu, dalam mengembangkan SDM dalam suatu organisasi faktor eksternal perlu dikembangkan. c) Perkembangan Ilmu Pengetahuan dan Teknologi: Perkembangan ilmu pengetahuan dan teknologi di luar organisasi dewasa ini telah sedemikian pesatnya. Organisasi yang baik harus mengikuti arus tersebut dan harus mampu memilih teknologi yang tepat. Untuk itu, kemampuan karyawan harus diadaptasikan dengan kondisi tersebut.

\section{Metode Penelitian}

Jenis penelitian

Penelitian ini merupakan pendekatan kualitatif dengan jenis deskriptif, sehingga metode yang digunakan adalah metode kualitatif. Penelitian ini menggunakan metode kualitatif karena untuk mendapatkan data yang lebih mendalam dan lebih natural. Data yang diperoleh merupakan data yang didapatkan langsung dari sumber yang tepat pada lokasi penelitian yaitu SMP Negeri 3 Jetis Bantul.

\section{Waktu dan tempat penelitian}

Waktu penelitian dilaksanakan pada bulan Desember 2012 sampai dengan April 2013. Penelitian ini dilakukan di SMP Negeri 3 Jetis Bantul.

Subjek dan objek penelitian

Subjek penelitian ini adalah 1 (satu) orang kepala sekolah selaku pemimpin yang bertanggung jawab terhadap sekolah, 1 (satu) orang wakil kepala sekolah bidang akademik, 4 (empat) orang perwakilan guru, dan 6 (enam) orang perwakilan siswa.

Objek penelitian ini adalah manajemen pengembangan profesionalisme guru di SMP Negeri 3 Jetis Bantul terdiri dari profesionalisme guru, manajemen pengembangan sumber daya manusia untuk me- 
ningkatkan profesionalisme guru, faktorfaktor penghambat dalam pelaksanaan pengembangan sumber daya manusia, usaha-usaha apa saja yang telah dilakukan oleh kepala sekolah dalam rangka mengatasi hambatan dalam pelaksanaan program manajemen pengembangan profesionalisme guru. Subjek penelitian adalah 1 (satu) orang ketua komite sekolah, 3 (tiga) orang anggota komite sekolah, 1 (satu) orang kepala sekolah, serta 2 (dua) orang guru yang dianggap mengetahui dan memahami peran komite SDN Sumberporong 03 Kecamatan Lawang Kabupaten Malang.

Teknik pengumpulan data

Pengumpulan data dilakukan dalam berbagai setting, berbagai sumber, dan berbagai cara. Dalam penelitan kualitatif, pengumpulan data dilakukan pada natural setting (kondisi yang alamiah), sumber data primer dan teknik pengumpulan data lebih banyak pada observasi berperan serta, wawancara mendalam dan dokumentasi. Dalam penelitian ini menggunakan teknik pengumpulan data sebagai berikut: 1) teknik wawancara: teknik wawancara dilakukan dengan cara mengadakan wawancara dengan orang-orang yang dianggap tahu tentang topik penelitian yaitu kepala sekolah, guru, dan siswa di SMP Negeri 3 Jetis Bantul. 2) teknik observasi: teknik observasi digunakan untuk memperoleh data tentang pelaksanaan hasil program pengembangan yang sudah ditempuh oleh guru, dalam kaitanya dengan kegiatan proses balajar mengajar dan kegiatan pelayanan yang besifat akademis para siswa. 3) dokumentasi; adapun fungsi dari teknik ini adalah untuk memperoleh data antara lain data tentang sejarah berdirinya SMP Negeri 3 Jetis Bantul, profil sekolah, struktur organisasi, data guru, program kerja, data kegiatan pengembangan yang telah dilakukan terutama kegiatan tentang peningkatan profesionalisme guru, kegiatan pengembangan untuk guru-guru, maupun data sarana dan prasarana sekolah.
Teknik keabsahan data

Menurut Lexy J. Moleong (2004, p.173) bahwa "pelaksanaan teknik pemeriksaan keabsahan data didasarkan atas sejumlah kriteria tertentu". Ada empat kriteria yang digunakan, yaitu derajat kepercayaan (credibility), keteralihan (transferability), ketergantungan (dependability), dan kepastian (confirmability). Teknik pemerik-saan keabsahan data yang dilakukan dalam penelitian ini adalah dengan trian-gulasi sumber yang merupakan bagian dari kriteria derajat kepercayaan.

Metode analisa data

Menurut Miles \& Huberman (1984, p.16) bahwa "analisis terdiri dari reduksi data, penyajian data, penarikan kesimpulan/verifikasi". Dalam penelitian ini, metode analisa data yang digunakan adalah analisis model interaktif. Analisis data berlangsung secara simultan yang dilakukan bersamaan dengan proses pengumpulan data dengan alur tahapan: reduksi data (data reduction), penyajian data (data display) dan kesimpulan atau verifikasi (conclution drawing $\mathcal{E}$ verifying). Dalam penelitian ini Reduksi data berlangsung terus-menerus selama proses penelitian berlangsung yaitu melaksanakan pemilihan data yang diperoleh dari wawancara, dengan kepala sekolah, guru dan siswa di SMP Negeri 3 Jetis Bantul dan pengumpulan dokumen-dokumen yang relevan tersebut.

\section{Hasil Penelitian dan Pembahasan}

SMP Negeri 3 Jetis Bantul Yogyakarta beralamat di Jalan Parangritis Km. 14,5 Patalan Jetis Bantul memiliki Visi "Mewujudkan insan cerdas, terampil, berakhlak mulia, dan berwawasan teknolgi informasi". Visi ini menjadi dasar bagi sekolah untuk selalu meningkatkan profesionalisme terutama guru. 
Profesionalisme Guru di SMP Negeri 3 Jetis Bantul Yogyakarta

\section{Kualifikasi akademik guru}

Kondisi profesionalisme guru di SMP Negeri 3 Jetis Bantul dipandang dari dua sisi. yaitu dari kualifikasi, bidang keahlian guru dan kompetensi guru. Merujuk pada Peraturan Pemerintah Nomor 19 Tahun 2005, bahwa kualifikasi akademik merupakan tingkat pendidikan minimal yang harus dipenuhi oleh seorang pendidik yang dibuktikan dengan ijazah atau sertifikat keahlian yang relevan sesuai dengan ketentuan perundang-undangan yang berlaku. Kualifikasi menunjukan bahwa para guru di SMP Negeri 3 Jetis Bantul yang pendidikan terakhir D2 sebanyak 2 orang atau $5,13 \%$, S1 sebanyak 35 orang atau $89,74 \%$, S2 sebanyak 2 orang atau $5,13 \%$. Jumlah keseluruhan guru yang mengajar di SMP Negeri 2 Jetis Bantul adalah 39 orang. Dengan demikian, kualifikasi akademik yang sebenarnya mengajar sebagai tenaga pengajar pada jenjang pendidikan menengah atau qualified adalah $94,87 \%$, sedangkan untuk yang 5,13\% adalah underqualified.

Kompetensi guru

Kompetisi guru adalah suatu pernyataan tentang kriteria yang dipersyaratkan, ditetapkan dan disepakati bersama dalam bentuk penguasaan pengetahuan, keterampilan dan sikap bagi seorang tenaga pendidik sehingga layak disebut kompeten. Tujuan adanya kompetensi guru adalah sebagai jaminan dikuasainya tingkat kompetensi minimal guru sehingga yang bersangkutan dapat melakukan tugasnya secara profesional, dapat dibina secara efektif dan efisien serta dapat melayani pihak yang berkepentingan terhadap proses pembelajaran, dengan sebaik-baiknya sesuai dengan bidang tugasnya. Kompetisi guru juga dapat ditunjukkan melalui prestasi-prestasi yang diraih sehingga dapat memotivasi belajar siswa maupun guru-guru lainnya untuk mengembangan keprofesionalan seorang guru di SMP Negeri 3 Jetis Bantul.
Kompetensi guru di SMP Negeri 3 Jetis Bantul diartikan sebagai pengetahuan, keterampilan, dan nilai-nilai dasar yang direfleksikan dalam kebiasaan berpikir dan bertindak. Arti lain dari kompetensi adalah spesifikasi dari pengetahuan, keterampilan, dan sikap yang dimiliki seseorang serta penerapannya di dalam pekerjaan, sesuai dengan standar kinerja yang dibutuhkan oleh lapangan. Dengan demikian, kompetensi yang dimiliki oleh setiap guru akan menunjukkan kualitas guru yang sebenarnya. Kompetensi tersebut akan terwujud dalam bentuk penguasaan pengetahuan, keterampilan maupun sikap profesional dalam menjalankan fungsi sebagai guru

Pengembangan Profesionalisme Guru di SMP Negeri 3 Jetis Bantul Yogyakarta

Pengembangan profesionalisme guru merupakan salah satu bentuk pengembangan SDM yang bertolak dari kebijakan dalam mengembangkan kemampuan profesionalisme ketenagaan untuk meningkatkan kualitas layanan akademik dan nonakademik. Tekanannya adalah pada peningkatan keahlian, keterampilan, perluasan wawasan, pembinaan semangat ilmiah, dan pengembangan budaya ilmiah para guru. Kegiatan pengembangan profesionalisme guru dapat dilakukan atas prakarsa instansi masing-masing, kelompok atau secara individu. Kegiatan pengembangan profesionalisme guru ini harus senantiasa dilakukan secara terus menerus seiring dengan perkembangan di berbagai bidang, ilmu pendidikan, ilmu pengetahuan, dan teknologi. Adapun usaha pengembangan profesionalisme guru oleh para guru SMP Negeri 3 Jetis Bantul dilakukan melalui berbagai bentuk, antara lain: pelatihan, aktif dalam kegiatan MGMP baik yang diselenggarakan oleh Dinas Kabupaten maupun diselenggarakan Dinas Pendidikan Provinsi. Mengikuti seminar, mencari informasi dari internet, diskusi dengan teman seprofesi, membuat media pembelajaran, dan dengan mambaca buku-buku yang dapat menunjang dalam kegiatan belajar mengajar. 
Pengembangan profesionalisme guru di SMP Negeri 3 Jetis Bantul diwujudkan melalui membaca koran/majalah tentang materi ajar, browsing internet, mengikuti MGMP, penelitian, dan memotivasi diri untuk meningkatkan mutu guru. Dengan demikian guru akan mengalami peningkatan dalam proses pembelajaran serta guru tidak ketinggalan informasi pembelajaran yang terkini.

Pelaksanaan Manajemen Pengembangan Profesionalisme Guru di SMP Negeri 3 Jetis Bantul Yogyakarta

Pelaksanaan program pengembangan bagi guru di SMP Negeri 3 Jetis Bantul dapat berjalan dengan efektif bila didukung dengan adanya peran serta secara efektif dari kepala sekolah dalam upaya untuk memberdayakan guru. Selain itu penyelenggaraan pengembangan dilakukan secara bertahap dan setiap tahapan dilakukan monitoring tentang kemampuan setiap guru dalam memahami dan menyerap program pengembangan yang telah dibuat akan menjadi efektivitas program pengembangan dapat tercapai secara efektif. Hal ini dilakukan dengan beberapa harapan supaya dapat mendukung kegiatan belajar mengajar di sekolah.

Program pelaksanaan pengembangan profesionalisme guru di SMP Negeri 3 Jetis Bantul mencakup aspek-aspek pengembangan SDM yang diwujudkan dalam bentuk-bentuk kegiatan-kegiatan yang meliputi peningkatan keahlian melalui studi lanjut, pelatihan atau musyawarah guru mata pelajaran (MGMP) serta studi banding. Untuk program pengembangan profesionalisme guru untuk peningkatan pengetahuan yaitu melalui penambahan koleksi buku, pembinaan guru melalui supervisi, dan pembinaan guru melalui penugasan. Adapun bentuk program pengembangan profesionalisme guru SMP Negeri 3 Jetis Bantul dilaksanakan melalui: a) Program pengembangan profesionalisme guru melalui kegiatan studi lanjut. b) Program pengembangan profesionalisme guru melalui kegiatan MGMP. c) Program pengembangan profesionalisme guru melalui penambahan koleksi buku pegangan untuk guru diperpustakaan. d) Program pengembangan profesionalisme guru melalui kegiatan supervisi. e) Program pengembangan profesionalisme guru melalui kegiatan penugasan.

Kerja sama Program Pengembangan Profesionalisme Guru di SMP Negeri 3 Jetis Bantul Yogyakarta

Berdasarkan hasil penelitian dalam pelaksanaan program pengembangan guru SMP Negeri 3 Jetis Bantul dalam rangka untuk meningkatkan profesionalisme guru perlu didukung oleh seluruh personil yang terlibat dalam program pengembangan SDM ini, termasuk adanya keterlibatan pihak lain yang terkait menjalin kerja sama dengan pihak-pihak terkait yang meliputi: (a) kerja sama dengan LPMP DIY dalam kegiatan pelatihan dan workshop, (b) kerja sama dengan Kanwil Departemen Pendikbud dalam kegiatan MGMP, (c) kerja sama dengan Dinas Pendidikan Provinsi dan Dinas Pendidikan Kabupaten Bantul dalam kegiatan MGMP dan MKKS, (d) kerja sama dengan LPMP DIY dalam menyiapkan nara sumber di berbagai kegiatan pelatihan.

Faktor-faktor yang Menghambat dan Upaya Mengatasi Hambatan Pelaksanaan Program Pengembangan SDM SMP Negeri 3 Jetis Bantul

Faktor-faktor yang menghambat pelaksanaan program pengembangan SDM SMP Negeri 3 Jetis Bantul.

Berdasarkan hasil penelitiaan di lapangan dapat peneliti kemukakan bahwa ada beberapa faktor yang menjadi penyebab pelaksanaan program pengembangan SDM dalam rangka untuk meningkatkan profesionalisme guru di SMP Negeri 3 Jetis Bantul belum dapat berjalan dengan baik. Faktor-faktor penyebab tersebut antara lain: 1) Keterbatasan anggaran sekolah. 2) Minat dan motivasi dari beberapa guru untuk mengikuti program pengembangan yang masih kurang. 3) Sulitnya menentu- 
kan waktu program pengembangan yang tepat.

Langkah-langkah yang ditempuh oleh kepala sekolah dalam mengatasi hambatan pengembangan SDM SMP Negeri 3 Jetis Bantul.

Sebagai langkah untuk mengatasi berbagai permasalahan yang berkaitan dengan pelaksanaan program pengembangan SDM untuk meningkatkan profesionalisme guru SMP Negeri 3 Jetis Bantul, maka kepala sekolah menempuh beberapa cara untuk mengatasi hambatan tersebut, sekolah melakukan langkah-langkah yaitu dengan mengajukan proposal permohonan bantuan kepada pemerintah melalui dinas pendidikan DIY sebagai berikut: 1) Menambah anggaran dana pengembangan profesional guru pada BOS. 2) Memberikan motivasi terhadap guru-guru untuk mengikuti program pengembangan guru. 3) Penentuan waktu pelaksanaan program pengembangan SDM. Juga kepala sekolah melakukan kerja sama dengan DIKDAS, MKKS, MGMP kabupaten, kecamatan, MKKM, LPMP kerja sama dengan perguruan tinggi seperti UNY, swasta: Lembaga AMT (Assessment Multivition Training) program pengembangan SDM.

\section{Pembahasan}

Profesionalisme Guru di SMP Negeri 3 Jetis Bantul Yogyakarta

Profesionalisme guru di SMP Negeri 3 Jetis Bantul dipandang sisi, kualifikasi dan kompetensi guru. Tingkat profesionalisme guru sangat ditentukan oleh kesesuaian tugas yang diberikan dengan kualifikasi akademik yang dimilikinya. Tugas yang diberikan jika tidak sesuai dengan keahlian dan kompetensinya akan mempengaruhi terhadap penguasaan materi yang diajarkan kepada siswa.

Hasil penelitian di lapangan menunjukkan bahwa guru di SMP Negeri 3 Jetis Bantul masih terjadi mismatched. Guru SMP Negeri 3 Jetis Bantul yang berjumlah 39 orang, yang mengajar belum sesuai dengan kompetensi keahliannya sebanyak 2 orang atau 5,13\%. Guru yang mismatched adalah 1 orang dari program studi keahlian Seni Budaya yang memiliki latar belakang pendidikan Seni Musik.

Kepala sekolah beralasan bahwa ketidaksesuaian untuk guru Program Studi Seni Musik karena sekolah berhadapan dengan manajemen. SMP Negeri 3 Jetis Bantul sebagai sekolah negeri tinggal menerima pendidik yang diberikan oleh pemerintah melalui rekrutmen CPNS. Meskipun penerimaan tenaga pendidik itu berdasar permintaan sekolah atas kekurangan tenaga pendidik. Namun sekolah tidak diberi kesempatan untuk mengajukan kriteria tenaga pendidik sesuai kompetensi yang dibutuhkan oleh sekolah.

Guru yang mengajar sesuai dengan latar belakang pendidikan melakukan kegiatan belajar mengajar cukup baik. Baik dari persiapan, metode mengajar, metode evaluasi, pengembangan materi, maupun pengembangan profesionalismenya.

Persiapan administrasi mengajar guru SMP Negeri 3 Jetis Bantul telah disiapkan di awal tahun. Namun ada pula yang disiapkan menjelang pembelajaran pada topik tertentu. Alasan guru mempersiapkan administrasi mengajar di awal tahun adalah ingin mempersiapkan dengan baik kegiatan pembelajaran sesuai dengan kelender pendidikan yang telah ditentukan dari pemerintah khususnya Dinas Pendidikan. selain itu pembelajaran menjadi lebih terprogram tidak asal mengajar tanpa ada persiapan. Sedangkan alasan guru mempersiapkan administrasi mengajar menjelang pembelajaran dikarenakan adanya kesibukan karena mendapat tugas tambahan dari sekolah.

Metode mengajar guru juga bervariasi disesuaikan dengan topik yang sedang diajarkan. Metode yang sering digunakan adalah metode ceramah yang digunakan oleh guru. Alasan guru memilih metode ini karena bahan yang disampaikan terkadang disertai penjelasan dari beberapa buku yang tersedia dan topik pembahasan terlalu banyak pada setiap semester sehingga guru lebih banyak menggunakan metode tersebut. Disamping 
metode ceramah, guru juga menggunakan metode yang lainnya, seperti metode memahami teks, metode diskusi kelompok, dan metode diskusi kelas. Alasan guru menggunakan metode tersebut karena siswa akan lebih mudah memahami materi pelajaran dan suasana belajar di kelas menjadi lebih hidup karena siswa menjadi lebih aktif dalam mengikuti proses belajar mengajar. Berbagai metode yang digunakan oleh guru untuk menyampaikan materi pelajaran ke siswa menunjukkan bahwa kompetensi profesional guru di SMP Negeri 3 Jetis Bantul sudah dapat dikatakan berjalan dengan baik.

Penugasan bahan dari seluruh upaya pengembangan profesionalisme guru merupakan indikator tinggi rendahnya profesionalisme guru yang berimplikasi terhadap penerima dan daya serap siswa terhadap materi mata pelajaran. Bentukbentuk kegiatan pengembangan tersebut bertujuan untuk peningkatkan penguasaan bahan sampai pada informasi terbaru.

Usaha yang dilakukan oleh sekolah dalam rangka untuk meningkatkan komunikasi antara guru, orang tua siswa, dan masyarakat di SMP Negeri 3 Jetis Bantul sudah dapat berjalan dengan baik. Keterbukaan yang diimbaukan oleh kepala sekolah menghasilkan keberanian siswa mengadukan masalah guru yang jarang masuk kelas atau metode guru dalam mengajar yang kurang tepat. Suasana hubungan keterbukaan tersebut berfungsi kontrol terhadap guru, disamping melalui kehadiran dan jurnal kelas.

Profesionalisme pelaksanaan pembelajaran banyak ditentukan oleh kesadaran dan usaha pribadi guru dalam menyerap informasi baru, usaha transformasi dan sikap keilmuan, usaha penguasaan bahan, dan mendorong kemajuan belajar siswa secara terus menerus. Sementara intensitas proses pembelajaran di kelas relatif tinggi. Namun demikian, intensitas kehadiran individu guru menunjukkan adanya keterkaitan dengan kesibukan di luar sekolah.

Profesionalisme menekankan kepada penguasaan ilmu pengetahuan dan kemampuan manajemen beserta strategi penerapannya. Sebagai jabatan profesi, guru dalam melaksanakan tugas harus profesional. Seorang profesional adalah menyukai sekaligus menikmati apa yang dikerjakannya. Dimulai dari persiapan sampai evaluasi dari apa yang menjadi tuntutan profesinya untuk dapat mencapai hasil yang diharapkan secara efektif dan efisien, bukan menjadi beban yang menyulitkan dalam melaksanakan tugas.

Pelaksanaan Pengembangan Profesionalisme Guru di SMP Negeri 3 Jetis Bantul Yogyakarta

Pengembangan profesionalisme guru merupakan salah satu bentuk program pengembangan yang ditujukan kepada guru. Guru adalah sumber daya manusia dalam penentu keberhasilan penyelenggaraan pendidikan yang ada di SMP Negeri 3 Jetis Bantul. Untuk itu guru sebagai SDM harus dikelola supaya tujuan pendidikan dapat tercapai. Di sini perlu dan pentingnya manajemen pengembangan SDM yang ditujukan kepada guru tersebut. Perlu berarti pengembangan SDM harus dilakukan oleh pengelola sekolah. Penting berarti pengembangan SDM tersebut bermanfaat untuk meningkatkan kemampuan dan keterampilan guru dalam mengajar.

Hasil penelitian mengenai pengembangan profesionalisme guru di SMP Negeri 3 Jetis Bantul mencakup aspek pengembangan SDM yang diwujudkan dalam bentuk kegiatan-kegiatan yang meliputi kegiatan program pengembangan profesionalisme guru melalui kegiatan studi lanjut, program pengembangan profesionalisme guru melalui kegiatan penugasan.

Program pengembangan profesionalisme guru melalui kegiatan studi lanjut, studi lanjut merupakan program dalam upaya peningkatkan profesionalisme guru di SMP Negeri 3 Jetis Bantul melalui pengurangan guru yang underqualified dan sebagainya usaha pengembangan profesionalisme guru bagi guru yang melanjutkan pendidikannya ke jenjang S1. Untuk dapat melakukan pengembangan profesionalisme guru melalui program pendidikan (stu- 
di lanjut), Dinas Pendidikan memberikan bantuan beasiswa serta berbagai kemudahan bagi bagi guru-guru SMP baik negeri maupun swasta untuk meningkatkan pendidikannya sampai jenjang S1. Bagi guru yang tidak mendapat bantuan beasiswa dari Dinas Pendidikan, sekolah memberikan kemudahan izin kepada guru yang akan melanjutkan studi dengan biaya sendiri.

Guru di SMP Negeri 3 Jetis Bantul saat penelitian dilakukan yang menempuh studi lanjut jenjang S1 ada dua orang dan sampai saat ini masih aktif dalam rangka menyelesaikan pendidikannya. Sumber biaya yang digunakan dalam program studi lanjut dengan biaya sendiri. Namun dukungan yang dilakukan oleh pihak Dinas Pendidikan Kabupaten Bantul belum sepenuhnya mendapat respon yang positif para guru SMP Negeri 3 Jetis Bantul dengan berbagai alasan: usia yang sudah tua, dan sudah akan pensiun, alasan ekonomi keluarga, kesibukan dalam mengurus rumah tangga, dan sibuk dengan kegiatan mengajar di sekolah lain.

Program pengembangan profesionalisme guru melalui kegiatan MGMP. MGMP adalah kegiatan pertemuan guru dalam rangka untuk meningkatkan kemampuan guru dalam memberikan layanan akademik kepada siswa sesuai mata pelajaran yang dibidanginya. MGMP yang diikuti oleh guru-guru SMP Negeri 3 Jetis Bantul merupakan kerja sama dengan Dinas Pendidikan Kabupaten Bantul dan Dinas Provinsi DIY melalui MKKS serta kerja sama dengan DIKDAS DIY.

Kegiatan MGMP yang dilaksanakan di SMP Negeri 3 Jetis Bantul sudah berjalan dengan baik. Bahkan pihak manajemen sekolah yaitu kepala sekolah sungguh sangat mendukung kegiatan MGMP ini. Kepala sekolah juga selalu mengingatkan guru untuk tidak lupa mengikuti kegiatan MGMP dengan penuh tanggung jawab. Kepala sekolah juga mengawasi pelaksanaan MGMP yang diikuti oleh guru-guru juga mengevaluasi hasil terhadap dampak perkembangan guru dalam mengajar, sehingga kegiatan MGMP ini bermanfaat sekali bagi guru-guru SMP Negeri 3 Jetis Bantul.

Program pengembangan profesionalisme guru melalui koleksi buku pegangan untuk guru di perpustakaan. Penambahan koleksi buku untuk guru di perpustakaan dilakukan pada tiap awal tahun pelajaran, terkadang juga dapat dilakukan pada awal tiap semester dan setiap adanya pergantian kurikulum yang berupa bukubuku referensi guru dan buku pelajaran pokok sebagai bahan literatur guru untuk mengajar. Kedua buku sebagai bentuk penambahan koleksi buku berkisar pada buku bahan ajar guru dan penunjangnya dalam melaksanakan tugas.

Jika melihat dari program kerja pengelola sekolah, kegiatan ini sudah cukup berhasil. Artinya, pada awal tahun pelajaran atau awal semester, guru diberikan kedua kategori buku tersebut, tetapi bila dilihat dari program pengembangan SDM, kegiatan tersebut belum cukup sebab disamping buku-buku sebagai bahan ajar dan penunjangnya juga dibutuhkan bukubuku lain sebagai bahan bacaan guru untuk menambah wawasan guru. Oleh karena itu sekolah harus menyediakan ruang perpustakaan guru dengan berbagai kelengkapan koleksi semua buku-bukunya.

Program pengembangan profesionalisme guru melalui kegiatan supervisi. Supervisi guru merupakan kegiatan supervisi kelembagaan yang dilakukan oleh kepala sekolah dengan menggunakan instrumen yang sesuai sebagai tenaga pengajar. Pemanfaatan hasil supervisi terhadap guru ini adalah memberikan saran-saran perbaikan dan memberikan penyelesaian masalah yang ditemui oleh guru. Kegiatan supervisi bertujuan untuk meningkatkan kinerja bagi tenaga kependidikan khususnya guru. Selain itu, supervisi merupakan kegiatan preventif untuk mencegah agar para guru tidak melakukan penyimpangan dan lebih berhati-hati dalam melaksanakan tugasnya. Pemanfaatan hasil supervisi terhadap guru ini adalah memberikan saransaran perbaikan dan memberikan penyelesaian masalah yang ditemui oleh guru dalam menjalankan tugasnya, seperti ma- 
salah yang berkaitan dengan pemilihan alat-alat pembelajaran, metode mangajar yang lebih baik yang sesuai dengan kondisi dan kemampuan siswa, serta cara-cara penilaian yang lebih sistematis.

Program pengembangan profesionalisme guru melalui kegiatan penugasan. Pembinaan guru melalui penugasan mempunyai pengaruh secara sinergis terhadap etos kerja guru. bentuk sinergi terhadap penugasan tersebut bergantung kepada sikap dan keterampilan guru. Penugasan yang diberikan kepada guru dapat berupa tugas pokok dalam Kegiatan Belajar Mengajar (KBM) maupun pemberian tugas tambahan di luar KBM.

Bentuk kegiatan adalah keikutsertaan akan kesadaran nasional, seperti peringatan hari kemerdekaan, upacara bendera setiap hari Senin, kegiatan keagamaan, penyediaan sarana peribadatan, dan kunjungan keluarga yang sakit dan yang meninggal dunia. Dari berbagai kegiatan tersebut terdapat rasa kekeluargaan yang lebih baik erat antarwarga sekolah.

Bila program pengembangan profesionalisme guru sebagai bentuk program pengembangan SDM yang terdapat di SMP Negeri 3 Jetis Bantul dibandingkan dengan definisi operasional penelitian dapat diketahui bahwa program pengembangan SDM untuk meningkatkan profesionalisme guru SMP Negeri 3 Jetis Bantul telah dilaksanakan, tetapi pengelolaanya belum optimal.

Faktor yang menghambat dan upaya mengatasi hambatan pelaksanaan pengembangan profesionalisme Guru di SMP Negeri 3 Jetis Bantul Yogyakarta

Keterbatasan jumlah anggaran di SMP Negeri 3 Jetis Bantul menjadi faktor penghambat terlaksananya program pengembangan profesionalisme guru. Banyaknya kegiatan pelatihan, seminar, workshop yang seharusnya diikuti oleh guru tidak sebanding dengan anggaran yang disediakan oleh sekolah. Anggaran mencerminkan komitmen manajemen terhadap usaha pencapaian sasaran yang telah ditentukan. Dalam penentuan ang- garan harus ditekankan bahwa alokasi anggaran yang tidak selalu diartikan sebagai berkurangnya tingkat komitmen manajemen terhadap pencapaian sasaran yang telah ditentukan sebelumnya, yaitu akibat faktor internal dan eksternal yang mengharuskan dilakukannya penyesuaian. Anggaran merupakan instrumen operasionalisasi jangka pendek dalam rangka mencapai sasaran jangka panjang yang biasanya memang memerlukan penahapan, dengan cukup tersedianya anggaran yang mendukung kelancaran program pengembangan.

Pelaksanaan program pengembangan SDM akan berjalan dengan baik bila didukung adanya sumber dana yang memadai untuk pelaksanaan kegiatan operasional tersebut. Di SMP Negeri 3 Jetis Bantul, faktor anggaran yang menjadi salah satu penyebab banyaknya program pengembangan SDM tidak berjalan sesuai dengan waktu yang telah direncanakan sebelumnya. Keterbatasan anggaran sekolah membuat pimpinan sekolah harus jeli dan teliti untuk memilih mana program pengembangan yang pelaksanaannya harus segera dilaksanakan dimana program pengembangan yang pelaksanaannya harus ditunda. Dalam pelaksanaannya kepala sekolah menyesuaikan jadwal program kepala sekolah yang sudah diprogramkan melalui kajian-kajian, sehingga dapat dilaksanakan dalam setiap tahun ajaran baru, sesuai dengan target yang dibuat untuk dapat dilaksanakan 3 kali setahun dan waktunya disesuaikan, sesuai yang dijadwalkan.

Keberhasilan sekolah sebagai lembaga pendidikan di dalam mencetak SDM yang berkualitas sangat ditentukan oleh peran kepala sekolah dalam perencanaan, pengorganisasian, pengerakkan, dan menyelaraskan sumber daya pendidikan. Oleh karena itu kepala sekolah dituntut untuk memiliki kemampuan manajemen dan kepemimpinan yang tangguh, karena kepemimpinannya sebagai faktor pendorong untuk mewujudkan visi, misi, dan tujuan sekolah. Sebagai pemimpin tertinggi di sekolah kepala sekolah harus mampu 
memobilisasi sumber daya sekolah, perencanaan, dan evaluasi program, kurikulum pembelajaran, pengelolaan personalia, sarana dan sumber belajar, keuangan, pelayanan siswa, hubungan dengan masyarakat dan penciptaan iklim yang kondusif di sekolah.

Peningkatan profesionalisme guru membutuhkan penanganan yang serius dari semua komponen yang ada di sekolah, karena hal tersebut bermuara pada mutu pendidikan. Perkembangan pendidikan dan ilmu pengetahuan yang cepat memberi dampak pada keharusan SDM pelaksanaannya untuk ikut berkembang pula.

Keseriusan penanganan pengembangan SDM akan berdampak keseriusan guru dalam mengikutinya. Untuk itu dituntut adanya peran dan partisipasi aktif dari kepala sekolah terhadap pelaksanaan program pengembangan melalui langkahlangkah kongkret. Pihak guru yang membidangi program pengembangan sumber daya manusia dituntut untuk lebih profesional dan di tuntut agar mampu berperan sebagai fasilitator dalam memecahkan setiap permasalahan yang ada. Hal ini dilakukan dengan harapan adanya pelaksanaan program pengembangan terhadap guru benar-benar mempunyai kedudukan sebagai tenaga pengajar yang profesional dalam pelaksanaan proses kegiatan belajar mengajar. Kekurangminatan dan tidak adanya motivasi guru dalam mengikuti program pengembangan berkaitan dengan tingkat kesejahteraan guru.

Kurangnya minat dan motivasi dari beberapa guru untuk mengikuti program pengembangan karena penghasilan yang diperoleh guru belum mampu untuk memenuhi kebutuhan hidup harian keluarga secara mencukupi. Oleh karena itu upaya untuk melanjutkan sekolah, menambah pengetahuan dan informasi dalam bidang pendidikan menjadi terhambat karena dana. Bahkan untuk memenuhi kebutuhan sehari-hari harus melakukan pekerjaan lain. Kurang minat guru untuk menambah wawasan sebagai upaya meningkatkan tingkat profesionalisme disebabkan karena bertambah atau tidaknya pengetahuan dan kemampuan dalam melaksanakan tugas rutinnya sebagai seorang guru tidak berpengaruh terhadap pendapatan yang diperolehnya. Kalaupun ada hal tersebut tidak berimbang dengan pengorbanan yang telah dikeluarkannya. Usia beberapa guru yang relatif sudah tua, bahkan ada beberapa guru hampir memasuki masa pensiun sehingga menyebabkan produktivitas kerja mereka untuk mengikuti program pengembangan mulai menurun.

Sulitnya menentukan waktu program pengembangan yang tepat merupakan salah satu faktor penghambat dalam program pengembangan SDM. Hal ini disebabkan guru mempunyai jadwal kegiatan dan kesibukan yang berbeda antara satu dengan yang lainnya. Pelatihan yang diselenggarakan oleh sekolah selama ini banyak menggunakan waktu belajar tidak aktif, seperti pada saat liburan semester sehingga kepentingan/hak siswa tidak dikorbankan. Selain itu pelatihan-pelatihan menggunakan waktu libur, karena menggangap mengganggu acara untuk keluarga. Demi kepentingan dan demi kebaikan bersama biasanya guru-guru dapat mengikuti dengan penuh kesadaran.

Usaha-usaha yang dilakukan kepala sekolah dalam mengatasi faktor penghambat pengembangan Profesionalisme Guru di SMP Negeri 3 Jetis Bantul Yogyakarta

Untuk mengatasi faktor penghambat pelaksanaan program pengembangan SDM untuk meningkatkan profesionalisme guru SMP Negeri 3 Jetis Bantul, maka kepala sekolah menempuh beberapa cara untuk mengatasi hambatan tersebut, antara lain: untuk mengatasi kekurangan anggaran dalam penyelenggaraan pengembangan SDM, kepala sekolah menambah anggaran dana pengembangan profesionalisme guru pada RAPBS yang diajukan kepada pemerintah.

Memberikan motivasi terhadap guru-guru untuk mengikuti program pengembangan SDM. Bentuk motivasi adalah dengan cara memberikan penghargaan (reward) bagi guru yang berprestasi. 
Penentuan waktu pelaksanaan program pengembangan SDM yang tepat agar dapat diterima oleh semua pihak dan tidak merugikan siswa adalah melalui jalur musyawarah antara kepala sekolah sebagai penanggung jawab kegiatan dan guru/ pegawai sebagai peserta pengembang. Hal ini dapat diterapkan pada kegiatan program pengembangan yang dilaksanakan oleh internal sekolah. Sedangkan kegiatan program pengembangan yang dilaksanakan pihak eksternal sekolah, waktu pelaksanaannya sudah ditentukan oleh penyelenggara sehingga peserta pelatihan tidak dapat memilih waktunya.

Ketidakpastian SDM yang dipilih untuk mengikuti program pengembangan menunjukkan bahwa perencanaan program tersebut belum terencana dengan baik dan cermat. Baik artinya perhatian penuh, keseriusan, dan dilakukan sesuai prosedur manajemen. Cermat artinya ketelitian dalam penetapan jadwal, penentuan SDM yang mengikuti, sampai penetapan alokasi dana. Dengan ini, dapat dikatakan bahwa manajemen pengembangan SDM yang ada belum berjalan secara optimal mulai dari perencanaan, pelaksanaan, pengawasan, pengedalian, serta evaluasi terhadap program. Apalagi jika dikaitkan dengan kegiatan sebelum perencanaan, yaitu analisis kebutuhan dan desain pengembangan. Akibatnya pelaksanaan program tidak dapat berjalan sesuai yang direncanakan, bahkan beberapa program pengembangan yang telah direncanakan tidak dapat dilaksanakan.

\section{Simpulan dan Saran}

Simpulan

Manajemen pengembangan profesionalisme guru di SMP Negeri 3 Jetis Bantul dapat disimpulkan sebagai berikut:

Kondisi profesionalisme guru di SMP Negeri 3 Jetis Bantul dalam rangka peningkatan profesionalisme guru. Dilihat dari kualifikasi akademik guru masih ada ketidaksesuaian kualifikasi akademik dengan tugas mengajar (mismatch) karena proses rekrutmen CPNS kurang memperhatikan bidang tugas guru yang dibutuhkan. Kesempatan pendidikan dan pelatihan yang ada belum dimanfaatkan secara optimal karena keterbatasan waktu, anggaran dan motivasi diri untuk mengembangan profesionalismenya juga terbentur jadwal dengan kepentingan keluarga/pribadi.

Pelaksanaan program pengembangan profesionalisme SDM (guru) di SMP Negeri 3 Jetis Bantul dalam rangka meningkatkan profesionalisme guru diwujudkan dalam bentuk pendidikan dan pelatihan. kegiatan-kegiatan antara lain: peningkatan keterampilan dan keahlian melalui pelatihan sosialisasi KTSP dan pelatihan komputer, studi lanjut, MGMP untuk masing-masing guru bidang studi, seminar, workshop. Peningkatan pengetahuan melalui penambahan koleksi buku-buku di perpustakaan. Pembinaan guru melalui supervisi dan penugasan. Dalam melaksanakan program pengembangan SDM guru SMP Negeri 3 Jetis Bantul melakukan kerja sama dengan: (a) Beberapa perguruan tinggi dalam kegiatan program studi lanjut, (b) Dinas Pendidikan Provinsi DIY, Dinas Pendidikan Kabupaten Bantul, Kanwil DIY dalam kegiatan pelatihan, MGMP, dan MKKS, (c) LPMP Provinsi DIY dalam kegiatan workshop. (d) Lembaga swasta dengan AMT (Asessment Multivition Training)".

Faktor-faktor yang menghambat pelaksanaan program pengembangan SDM dalam rangka meningkatkan profesionalisme guru di SMP Negeri 3 Jetis Bantul antara lain: (1) terbatasnya anggaran dari sekolah, (2) minat dan motivasi dari beberapa guru untuk mengikuti program pengembangan yang masih kurang. (3) sulitnya menentukan program pengembangan yang tepat.

Usaha yang dilakukan oleh kepala sekolah dalam mengatasi hambatan tersebut antara lain: (a) kepala sekolah mengajukan penambahan anggaran untuk program pengembangan guru pada RAPBS kepada pemerintah. (b) kepala sekolah memberikan motivasi kepada guru tentang pentingnya program pengembangan guru 
dan memberikan reward kepada guru yang berprestasi. (c) kepala sekolah melaksanakan program pengembangan pada libur semester atau setelah proses kegiatan belajar mengajar selesai, dan (d) kepala sekolah melakukan kerja sama dengan intansi terkait yang berkompeten seperti Dinas Pendidikan Kabupaten Jetis dan LPMP Provinsi DIY dan juga mengadakan kerja sama dengan pihak swasta.

\section{Saran}

Berdasarkan hasil penelitian, maka saran-saran yang dapat diberikan adalah sebagai berikut:

Perencanaan program pelatihan di sekolah dilakukan melalui: (a) assesmen kebutuhan program pelatihan secara komprehensif untuk menentukan waktu, tujuan, pengaturan waktu pelaksanaan dan jadwal, struktur program dan silabi serta alokasi dana pelatihan, (b) perumusan tujuan pelatihan secara spesifik agar apa yang ingin dicapai melalui pelatihan tergambar secara jelas dan mempermudah dalam mengukur pencapaian tujuan, (c) perencanaan disain kegiatan pelatihan bagi guru sebagai peserta pelatihan terdiri dari teori dan praktik, sehingga penguasaan kompetensi guru menjadi komprehensif, (d) perencanaan waktu dan tempat pelaksanaan pelatihan melibatkan seluruh komponen guru, dan waktu pelatihan yang telah dialokasikan harus dipergunakan secara optimal, (e) penyusunan alokasi dana pelatihan dilakukan secara cermat agar seluruh kebutuhan pelatihan dapat diakomodasi. Penyediaan dana harus disesuaikan dengan program pelatihan yang telah disusun.

Program pengiriman peserta diklat, (a) perencanaan disusun dalam bentuk program tahunan kepala sekolah secara terstruktur meliputi jenis diklat, peserta diklat, waktu pelaksanaan, dan alokasi dana, (b) pengiriman peserta pelatihan didasarkan pada hasil supervisi dan penilaian tahunan kepala sekolah, (c) pemantauan dan evaluasi dilakukan untuk pelak- sanaan pelatihan selanjutnya yang lebih baik.

Tingkat pengawasan kepala sekolah perlu dioptimalkan, sehingga pelaksanaan pengembangan SDM bagi guru yang sudah direncanakan dapat berjalan dengan baik. Selain itu kepala sekolah terus menerus memberikan motivasi kepada semua guru-guru untuk aktif dalam mengikuti semua kegiatan pengembangan profesionalisme guru baik yang diselenggarakan oleh intern sekolah maupun yang diselenggarakan oleh ekstern sekolah.

Evaluasi terhadap program pengembangan harus dilakukan secara terus menerus, sehingga setiap permasalahan yang berkaitan dengan program pengembangan SDM dapat segera diatasi. Program pengembangan tersebut diharapkan dapat meningkatkan profesionalisme guru yang pada akhirnya program pengembangan tersebut nantinya dapat memberikan kontribusi bagi kualitas pendidikan terutama dalam meningkatkan profesionalisme guru dalam kegiatan pembelajaran.

Upaya untuk perubahan yang diinginkan berkaitan keberhasilan sekolah SMP Negeri 3 Jetis Bantul, sebaiknya membentuk tim Program Keprofesian Berkelanjutan (PKB) tingkat sekolah terutama pada komponen publikasi ilmiah dan karya inovatif.

\section{Daftar Pustaka}

Beebe, S. A., Mottet, T.P. \& Roach, K.D. (2004). Training and development: Enhancing communication and leadership skill. New York: Pearson.

Decenso, D.A \& Robbins, S.P. (1999). Human resources management. New York: John Wiley \& Sons.

Hamzah B. Uno. (2007). Profesi kependidikan: problema, solusi, dan reformasi pendidikan di Indonesia. Jakarta: PT. Bumi Aksara.

Husaini Usman. (2011). Manajemen teori, praktik, dan riset pendidikan. Edisi 3. Cet.3. Jakarta: PT. Bumi Aksara. 
Moleong L. J (2004). Metodologi penelitian kualitatif. Bandung: PT. Remaja Rosdakaya.

Miles, M. B. \& Huberman, A. M. (1984). Qualitative data analysis. A. Sourcebook of new methods. London New Delhi: Sage Publications Beverly Hills.

Soekidjo, N. (1992). Pengembangan sumber daya manusia. Jakarta : PT. Rineka Cipta.

Soetjipto \& Raflis, K. (2009). Profesi keguruan. Jakarta: PT. Rineka Cipta.
Undang-Undang Republik Indonesia Nomor 20 Tahun 2003 tentang Sistem Pendidikan Nasional. Bandung: Fokusmedia.

Undang-Undang Republik Indonesia Nomor 14 Tahun 2005 tentang Guru dan Dosen. Bandung: Fokusmedia. Undang-Undang Republik Indonesia Nomor 19 Tahun 2005 tentang Guru dan Dosen. Bandung: Fokusmedia 